\title{
PSYCHOLOGICAL SUPPORT OF THE DEVELOPMENT OF SOCIALLY ACTIVE YOUTH
}

https://doi.org/10.37096/SHDISJ-20-2.2-0005

\author{
Karamushka Margarita \\ ORCID ID: 0000-0003-4421-8178 \\ Vlasova Olena \\ ORCID ID: 0000-0002-9894-0038
}

\begin{abstract}
The article provides a theoretical substantiation and experimentally investigates the psychological support of the development of socially active youth. The study has been carried out on the materials of comparative research of psychological qualities of socially active and socially inactive youth to present advantages and limitations of the selected types of socially active youth, and also to describe experience of psychological support of the further development of their social activity.

Methodology. A model of the psychological qualities of socially active youth has been built (leadership development, value-motivational, emotionalregulatory and communicative components of psychological qualities) and the appropriate psychodiagnostic, statistical and developmental tools have been selected.

Results and discussion. Based on empirical research, the level of development of the indicated psychological qualities of its participants was revealed, differences between socially active and socially inactive youth were revealed. There are 5 types of socially active youth (according to the level of development of psychological qualities): leaders, communicators, impulsive, aggressive, avoiding communication young people.

There are statistically significant relationships between the psychological qualities of socially active youth and factors at the macro level (orientation of social activity of youth), meso level (type of organization in which youth is active), micro level (professional and socio-demographic characteristics of youth). The psychological conditions for the development of socially active youth have been determined. A training for the development of psychological qualities necessary for the implementation of the social activity of young people has been developed and tested.

Keywords: Social activity; psychological qualities, types of socially active youth; factors of development of socially active youth; psychological training.
\end{abstract}

\section{Introduction}

Relevance of research. Among the activity areas from which sustainable development of Ukrainian society largely depends, a special place belongs to the social activity of young people. The real progress of the country to the prosperity of the Ukrainian state and its individual citizens depends on how actively the young generation of modern Ukrainians acquires the experience of adequate understanding, objective vision of social perspectives and real planning of changes in the surrounding social reality.

The analysis of the literature shows that the problem of social activity of young people is interdisciplinary and it is reflected in various ways in the works of 
representatives of various humanities. Modern approaches to the study of human social activity are political and legal (O. Kindratets, M. Ostapenko, etc.), sociological (L. Kogan, S. Tsypko, etc.), socio-cultural (E. Anufriev, A. Kravchenko, etc.), pedagogical (M. Kolesnikova, V. Kosovets, O. Kulinchenko, O. Seredyuk, S. Cherneta, etc.), psychological (A. Bazylenko, O. Vlasova, S. Grabovska and S. Czolij, I. Zarubinska, L. Kiyashko, L. Snigur, etc.) and others.

According to the psychological approach on which this study is based, social activity of the individual is understood in two main manifestations: as a form of activity and as a personal quality, which in the system of philosophical - categorical analysis corresponds to the metaphysical interpretation of the unity of paired categories of actual and potential. According to the authors of the article, social activity is defined as the highest

\section{Theoretical background}

Analysis of publications of domestic and foreign authors showed that the psychological characteristics of social activity of youth are expressed in its content, structure of components, factors and conditions of development and are manifested through the types, directions and functions of social activity, as well as (what is essential for this article) - because of the psychological qualities of the individual that are necessary for its successful implementation.

The special role of psychological qualities of personality in the implementation of social activity is revealed in the studies of $\mathrm{K}$. Abulkhanova (1985), L. Bozhovich (1968), O. Vlasova (1989), O. Kyrychuk (1983), S. form of activity of the individual, which provides its deep and diverse links with society, which are realized in the process of socially useful activities of the individual. In this activity, based on formed psychological qualities, it realizes the needs and interests of society as a whole or individual social groups, transforms the given social environment and itself. An important role is played by subjective human activity, which is the core of social activity and determined by "internal" validation of personality (M. Boryshevsky, N. Volenyuk, V. Zenkovsky, S. Rubinstein, G. Chelpanov, etc.).

The purpose of the article is to present the advantages and limitations of the selected types of socially active youth, as well as to describe the experience of psychological support of further development of their social activity on the materials of comparative research of psychological qualities of socially active and socially inactive youth.

Grabovska, and S. Choliy (2010), R. Turenko and S. Yanovska (2018) and others. Thus social activity as quality of the person, on one hand, is characterized by socially valuable motives of the person, on the other - person's active behavior, ability not only to adapt to circumstances, and, above all, to change them in accordance with the social challenges that arise and the moral requirements in force in society. Thus, the psychological qualities of socially active youth are a set of psychological characteristics that a young person needs for the successful implementation of various types of social activity.

As internal psychological factors that are necessary for social activity, various researchers identify such psychological characteristics of human as 
the individual initiative (Sapriyanchuk, 2010), needs and motives (Vintyuk, 2010, Zinevych, Tsypko, 2016, etc.), leadership qualities (Sopivnyk, Yanovska, 2018), empathy (Gusev, 2019), the qualities of self-regulation of the individual, expressed independence and responsibility (Abulkhanova, 1985), (Tatenko, 2017)), prosocial orientation, responsibility and initiative of the growing person, its social abilities (Vlasova, 1989, 2019) and others.

Among the social and sociopsychological conditions for the successful development of social activity of youth in the literature, the peculiarities of the youth policy of the state (Murzina, 2019), the environment of the modern young city (Potapova, 2013), sociocultural environment of the village (Kosovets, 2009), youth formations and children's associations (Bespalko, Romanovska, 2009), etc., pupils' and students` self-government (Kulinchenko, 2015), Kosenchuk, 2013) and others), integration of formal and non-formal education (Kharlamova, 2019) are reasonably determined.

The author's conceptual model presented in Fig. 1 provides a study of 1) the structure of personality components of socially active youth as its psychological qualities and the system of macro-, mesoand micro-factors of such activity, as well as psychological conditions of psychological qualities of socially active person.

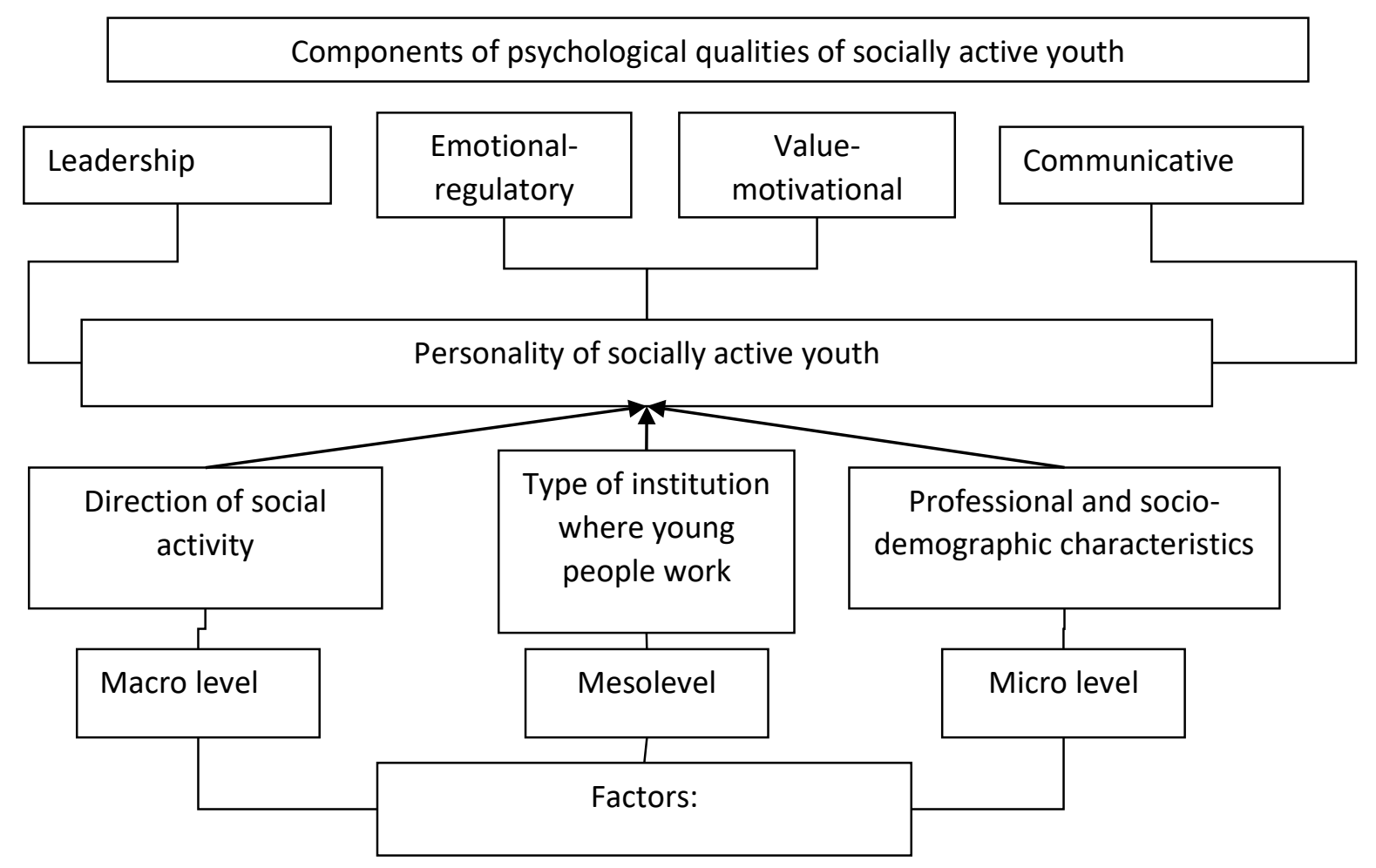

Fig. 1. Model of research of psychological features of socially active youth

Taking into account the available Vintyuk, 2010, Zinevych, 2013, literature sources (Abulkhanova- Sopivnyk, 2016, Yanovska, 2018 and Slavskaya, 1985, Bazilenko, 2016, etc.), the structure of psychological 
qualities of socially active youth is determined, which consists of leadership, value-motivational, emotional-regulatory and communicative components. The leadership component, in turn, is filled with the ability to lead as a person's initiation of activity (its and other people), its communication and organizational skills. The value-motivational component includes the level of development of individual altruism and such motives as the desire for success, recognition and respect, power as social control. The emotional-regulatory components include the degree of human satisfaction with their own social achievements and the prevailing strategies of their behavior in stressful situations. The self-confidence of a socially active person and communicative control as a mechanism for implementing responsible social behavior of people are the parts of the communicative component.

The main factors in the development of psychological qualities include the direction of social activity (macro-level factor), the type of institution in which young people are socially active (mesolevel factor), as well as professional and socio-demographic characteristics of youth as micro-level factors. The study of psychological conditions for the development of psychological qualities of socially active youth involves the development and implementation of special programs for their sociopsychological training.

Certain theoretical positions were the basis of empirical research of psychological features of development of socially active youth. The analysis allowed formulating the main hypotheses of empirical research:

1. There are differences in the manifestation of psychological qualities of socially active and socially inactive youth;

2. In the group of socially active youth there may be different types of young people who differ in the manifestation of psychological qualities related to leadership, value-motivational, emotional-regulatory and communicative components of social activity;

3. There is a connection between the manifestations of psychological qualities of socially active youth and factors related to: a) macro level (areas of social activity of youth); b) meso level (type of institution where young people do social activity); c) micro level (professional and socio-demographic characteristics of youth);

4. The psychological conditions for the development of psychological qualities of socially active youth include the introduction of a special training program, which provides mastery of training participants: a) knowledge of the psychological qualities of socially active youth; b) methods of diagnosis and analysis of their own psychological qualities necessary for the manifestation of social activity; c) skills and abilities necessary for social activity.

\section{Methodology}

Methods. To test the hypotheses in the work it was used a set of techniques, the choice of which depended on the content of the objectives of the study, built in the logic of the formative experiment:

- theoretical methods - analysis, generalization, systematization and interpretation of scientific sources, modeling;

empirical methods
psychodiagnostic
questioning) to study the basic psychological qualities of socially active youth and the method of psychological 
training for the implementation of active socio-psychological training of participants. Psychodiagnostic tools were used in the study to diagnose the following components of social activity: 1) leadership (methods "Ability to Leadership" by R. Nemov and "Methods for studying communicative and organizational tendencies (KOS-2)" by V. Synyavsky, B. Fedoryshyn); 2) valuemotivational ("Methods of motivators of social and psychological activity of the individual" by N. Fetiskin, V. Kozlov, G. Manuylov and "Methods for the study of personal "altruism-selfishness" attitude by O. Potemkina); 3) emotionalregulatory (S. Hobfall's Strategic Approach To Coping Scale (SACS) (adaptation of N. Vodopyanova, O. Starchenko) and method "Study of the level of social frustration" by L. Wasserman (adaptation of V. Boyko)); 4) communicative (Rathus Assertiveness Scale (RAS) and Snyder's SelfMonitoring Scale).

The author's questionnaire "Social activity of youth" with "open" questions was also used and the program of psychological training of development of social activity, which included a number of active methods of social and psychological training, was developed (case method, project method, discussion method, brainstorming, etc.).

- mathematical and statistical methods - descriptive statistics, correlation, factor, cluster and analysis of variance, the method of content analysis to study young people's ideas about the nature, forms and factors of social activity of youth, psychological conditions of psychological qualities of socially active youth. Mathematical data processing was performed using the SPSS statistical software package (version 17.0).
Sample. The study, which was conducted in Kyiv in 2015-2019, involved 232 persons. Among them there are 206 persons who were active in various social fields (participants of the Maidan events, representatives of the football fans association "Ultras", volunteerspsychologists, scholarship holders of the Victor Pinchuk Foundation program "ZAVTRA.UA", etc.). As well as 26 people who identified themselves as socially inactive. $28.2 \%$ of the total sample are men and $71.8 \%$ are women. The age of the subjects - 17-20 years old $30.1 \%$, from 21 to 30 years old $-69.8 \%$. Among them, $31.0 \%$ of young people have higher education, $31.0 \%$ have incomplete higher education. $44.5 \%$ of study participants have been the heads of working groups, departments or organizations, $55.5 \%$ have worked as employees of organizations.

\section{Results}

1. Empirical research of psychological features of development of socially active youth by means of questionnaires has shown that modern Ukrainian youth understands adequately essence of social activity. Most of them (42.9\%) attributed to such activity "any activity of young people (charitable, scientific, political, social, etc.) to improve life in various social spheres" (31.2\%). In addition, such answers were received as "participation in social projects, events, conferences, etc." $(11.7 \%)$, "creation or development of projects / organizations" (11.7\%), "assistance in the social life of youth" $(10.4 \%)$ and "clear life position, defending their rights, self-development" $(9.1 \%)$.

The forms of social activity of young people were included in the study: "volunteering" (41.6\%), sports, creative 
and other activity (organization of youth leisure) (32.5\%),"student activity" (24.7\%),"work in public associations" (14.3\%), "participation in political activity" (14.3\%), "participation in social projects" (14.3\%), "charity" (11.7\%), "participation in rallies, strikes, etc." (10.4\%), "assistance to participants in hostilities" (9.1\%), "assistance to others" (3.9\%). The participants of the study also determined the main directions of social activity of youth: scientific and educational (participation in the activities of scientific and educational funds, preparation and implementation of scientific and educational projects) $39.0 \%$; socio-psychological (work in volunteer organizations to provide psychological assistance to combatants) $18.2 \%$; cultural and artistic (work in cultural and artistic public associations, movements, etc.) - $16.9 \%$, business (youth business development, entrepreneurship, etc.) - $16.9 \%$, sports (sports development assistance) - 15.6\%, military-patriotic (participation in the organization and conduct of militarypatriotic events, organizational and economic assistance to participants in hostilities) - 10.4\%, medical field and ecology (work in medical and environmental organizations).

2. The main reasons that contribute to the development of social activity of young people in the current socioeconomic conditions of Ukraine, respondents consider "the unstable situation in the country and low living standards" (39.0\%), "desire for selfdevelopment" (18.2\%), "activity of public organizations" (14.3\%), "availability of funding for various projects" (14.3\%), "information in the media" (9.1\%), "promotion of social activity, in particular, in higher education institutions" ( $7.8 \%$ ) and others.

Among the reasons that hinder the development of social activity of Ukrainian youth were named: "lack of support from the state" (37.7\%), "lack of desire in the youth" (27.3\%), "lack of funding, the presence of other cases and responsibilities that do not allow to give their free time to social activity " $(19.5 \%)$," the inability of young people to adapt to today's conditions and actively act in them "(14.3\%). Significant in the context of the objectives of our study is that a significant number of respondents $(41.6 \%)$ indicated that young people do not have the necessary psychological qualities to do the social activity.

To study the psychological qualities of young people necessary for social activity, a comparative analysis of the development of these qualities in socially active and socially inactive youth has been conducted. Based on the data of all applied methods, the average statistical value for each scale for both groups has been determined. Further, during the analysis of variance (Fisher's test has been used), a statistically significant difference has been found between two groups of indicators (socially active and socially inactive youth) on the following scales: leadership ability $(\mathrm{F}=7.7, \mathrm{p}=0.001)$, organizational skills $(\mathrm{F}=3.58, \mathrm{p}=0.030)$, desire for power $(F=5.75, p=0.004)$, assertiveness $(\mathrm{F}=3.56, \mathrm{p}=0.031)$, manipulative actions $(\mathrm{F}=7.79, \mathrm{p}=$ $0.001)$, antisocial actions $(\mathrm{F}=6.84, \mathrm{p}=$ $0.001)$, frustration $(\mathrm{F}=6.08, \mathrm{p}=0.003)$. 
Thus, as a result of the features' analysis of psychological qualities development of socially active youth (leadership, value-motivational, emotional-regulatory

and communicative) it is established that the main psychological characteristics of socially active youth are high indicators of aspiration to success, the increased indicators of their assertiveness, organizational abilities and motivation for recognition and respect.

The motives of avoidance, aggressive and impulsive actions of such young people against the background of low indicators of their motivation of social contacts are also revealed. The obtained results have shown significant differences in the development of psychological qualities of socially active and socially inactive youth, as well as reveal a number of reserves in the development of psychological qualities of socially active youth.

3. Psychological research of types of socially active youth has been carried out using the procedure of factor analysis. These principal components of analysis have identified five factors that describe $62.04 \%$ of the sample variance (see Table 1).

Table 1. The results of factor analysis of indicators of socially active youth who participated in the study

\begin{tabular}{|l|r|r|r|r|r|}
\hline \multirow{2}{*}{\multicolumn{1}{c|}{ Variable }} & \multicolumn{5}{|c|}{ Factors } \\
\cline { 2 - 6 } & 1 & 2 & \multicolumn{1}{c|}{5} \\
\hline Communication skills & & & & \multicolumn{1}{c|}{4} & \\
\hline Organizational skills & 0,729 & 0,126 & $-0,174$ & 0,225 & 0,338 \\
\hline Ability to lead & 0,734 & 0,175 & 0,011 & $-0,209$ & 0,257 \\
\hline Altruism-selfishness & 0,826 & $-0,052$ & 0,187 & $-0,223$ & 0,027 \\
\hline Striving for success & 0,036 & 0,166 & $-0,361$ & $-0,294$ & 0,621 \\
\hline The desire for power & 0,581 & 0,306 & $-0,025$ & $-0,377$ & 0,042 \\
\hline The desire for recognition and respect & 0,480 & 0,378 & 0,527 & $-0,179$ & $-0,159$ \\
\hline Assertive actions & 0,338 & 0,732 & $-0,087$ & 0,073 & 0,098 \\
\hline Entering social contact & 0,613 & 0,123 & $-0,016$ & 0,031 & $-0,306$ \\
\hline Search for social support & 0,103 & 0,833 & 0,047 & $-0,067$ & 0,138 \\
\hline Precautions & 0,036 & 0,698 & 0,015 & $-0,021$ & 0,025 \\
\hline Impulsive actions & $-0,146$ & 0,625 & 0,245 & $-0,025$ & $-0,361$ \\
\hline Avoidance & 0,010 & $-0,008$ & 0,322 & 0,197 & 0,651 \\
\hline Manipulative actions & $-0,258$ & 0,217 & 0,099 & 0,753 & 0,151 \\
\hline Antisocial actions & 0,173 & 0,093 & 0,597 & 0,402 & $-0,161$ \\
\hline Aggressive actions & 0,066 & $-0,012$ & 0,848 & 0,135 & $-0,028$ \\
\hline Frustration & $-0,125$ & 0,043 & 0,747 & $-0,105$ & 0,167 \\
\hline Assertiveness & $-0,434$ & 0,013 & 0,281 & $-0,054$ & 0,047 \\
\hline Communicative control & 0,774 & $-0,003$ & 0,235 & $-0,014$ & $-0,056$ \\
\hline
\end{tabular}

The first factor has included scales: "leadership" (0.826), "assertiveness" (0.774), "organizational skills" (0.734), "communication skills" (0.729), "assertive actions" (0.613), "success" (0.581). The "negative" pole of the factor has combined the scales "frustration" (- 0.434), "avoidance" (- 0.258) as significant projections.

Descriptively, the "leaders" factor brought together the psychological characteristics of young people who 
aspire to leadership, have high communication and organizational skills, show assertiveness (coping strategy «assertive actions») and are focused on success. It is not typical for them to use coping strategies of "avoidance" (not focused on solving life's problems) and "social frustration" (based on dissatisfaction with life's achievements).

Scales represent the second factor, which in terms of psychological characteristics is called «communicators»: coping strategy "entring social contact" (0.833), "desire for recognition and respect" (0.732), "search for social support" (0.698), "precautions» (0.625). The pole of "declining" values includes the scale "communicative control" (- 0.182).

Young people, who have these qualities, are positive about the interests of others, are quick to make concessions, and can use a strategy of compromise and even ignoring their own interests to make "everyone comfortable". This implies their tact, high emotional competence, ease of establishing contacts and making new acquaintances. They are diligent executors, can successfully negotiate, and conscientiously perform the assigned work.

The content of the third factor is filled with such scales as "antisocial actions" (0.848), "aggressive actions" (0.747), "manipulative actions" (0.597), "desire for power" (0.527), "altruismegoism" with a predominance of values, indicating the absence of altruism in the person $(-0.361)$. According to the set of variables that are represented in its structure, the factor and the corresponding type of youth are called "aggressive". It describes young people who know how to achieve their goals, although not always in humane ways. Representatives of this type are determined and self-confident, quickly reach management positions, for which they can manipulate information, other people, but it is difficult for them to work in a team. Usually such people think first of their own interests and can engage in social activity to achieve personal goals, self-affirmation and selfrealization, while the motives of helping others or prosocial activity recede into the background.

The fourth factor has included variables on the scales "avoidance" (0.753) and "communicative control" (0.717). At the pole of negative values are the indicators of the scales "success" (- 0.377) and "desire for power" (- 0.179). According to the content of scales integrated into the factor, such representatives of socially active youth can be called "avoiding". They are characterized by an attempt to avoid active contacts and work independently. But they also try to achieve socially significant goals in their activities and therefore do the social activity. Low rates of motive for the success of these individuals mean that in the organization of their activities they have a different strategy - to avoid failure). At the same time, they are highly effective in selfcontrol, including their own statements. Typically, such people are not risky, and do only the things that they are sure of.

The fifth factor is represented by variables such as "impulsive actions" (0.651) and "altruism-egoism" (0.621), as well as "cautious actions" (-0.361) and "assertive actions" (-0.306). According to the content of the scales of the representatives of this group, they can be classified as "impulsive", and therefore have the desired result. This type of socially active person is most distinguished by impulsiveness and 
altruism. Such young people tend to act rather than think, they can inspire others, but their own activity is not always organized and independent. At the same time, they are not inclined to behave correctly in relation to others, persistently defend their point of view, and emotionally react to objections from others, negative statements or actions about themselves or their business. They are not characterized by assertiveness as the ability to effectively withstand the psychological pressure of the environment.

The results of cluster analysis complement the data of factor analysis and confirm the presence of five types of socially active youth (according to the level of development of psychological qualities): "leaders", "communicators"; "aggressive"; "avoiding"; iImpulsive", and also allowed to establish their quantitative representation. In particular, the group of "leaders" included $35.2 \%$ of young people surveyed, "communicative" - 22.5\%, "aggressive" - 16.9\%, "avoidant" - $15.5 \%$ and "impulsive" - $9.9 \%$. This indicates that according to the current study of socially active youth, the third of respondents belongs to the type of "leaders". Young people who belong to the other types, combined into four groups, are not psychologically "leaders", but they are also socially active and manifest themselves in various areas of social activity (scientific, patriotic, sports, charity, etc.), implementing their style of social activity. Therefore, in the process of interaction with different categories of socially active youth should take into account the psychological characteristics of each of the identified groups both in terms of their positive characteristics and in terms of limitations that are presented in the psychological portrait of each type.
Empirical study using correlation analysis of factors of development of psychological qualities inherent in different types of socially active youth have showed that among the macro- and meso-level factors on the development of psychological qualities of socially active youth are influenced by the following: 1) for the group of "leaders" - work in a government organization $(\mathrm{r}=0.185, \mathrm{p}=$ $0.028)$; 2) for the group of "communicators" - sports $(r=0,182, p=$ $0,031)$, socio-psychological $(r=0,235, p$ $=0,005)$, military-patriotic $(\mathrm{r}=0,192, \mathrm{p}=$ 0,022) spheres; 3) for the group of "aggressive" - business $(\mathrm{r}=0,188, \mathrm{p}=$ $0,025)$; 4) for the group of "avoiders" cultural and artistic sphere $(r=0.190, p=$ $0.024)$; 5) for the group of "impulsive" work in a government organization $(\mathrm{r}=$ $0,194, p=0,020)$.

Such data indicate that the state type of organization in which respondents work correlates with groups of "leaders" and "impulsive".

It is obvious that "leaders" in publictype organizations can find support for their desire to advance to a higher position, as well as to confirm their leadership status through this position, while in private organizations the connection between position and personal qualities is not obvious. As for the type of "impulsive", it is seen that clear regulation of work in government agencies can have a positive effect on reducing this quality of socially active young people. For "communicators" the development of appropriate qualities is supported by work in the social-charitable, military-patriotic and sports spheres, which is explained by the specifics of work in the field of "human-human", where communication 
is the main means of performing work that involves the presence of personal qualities that are important for social activity. For a group of "aggressive" work in the business sphere helps to improve the qualities needed to carry out their social activity. Probably, these young people have a personal experience of combining entrepreneurial and socially active activities allows them to be quite tough, persistent in the situation of achievement and more "soft", "understanding" in the situation of interpersonal interaction. For the "avoiders" the artistic sphere turned out to be much related, because, as the positive correlation indicates, it is the experience of individual creative activity that enhances the manifestations of such a personality to the level necessary for its successful prosocial activity.

It is also established that the professional factors for the development of psychological qualities of socially active youth are: 1) for "leaders" - a position in the organization $(r=-0.226, p$ $=0.003)$ and level of education $(\mathrm{r}=0.252$, $\mathrm{p}=0.003)$; 2) for "avoiding" work experience $(\mathrm{r}=0.305, \mathrm{p}=0)$. The data obtained show that the career growth of young people in the organization contributes to the development of such representatives of leadership skills. This is due, in particular, to an increase in the direct responsibilities of a young person holding a certain position. It is also established that the level of education of a person significantly correlates with the development of psychological qualities necessary for his social activity, as it expands the "vision" of young people in the range of possible areas of activity. Instead, a longer work experience more often assigns a "strategy of avoiding failures" to a young person, reducing the manifestation of those qualities that are necessary for successful social activity.

The study has found that sociodemographic factors in the development of psychological qualities of socially active youth are: 1) for "leaders" - having children ( $r=0.208, p=0.016)$; 2) for "communicators" - gender $(\mathrm{r}=0.188, \mathrm{p}=$ $0.03)$ and place of residence $(r=0.186, p$ $=0.031)$; 3) for "aggressive" - marital status $(\mathrm{r}=-0.304, \mathrm{p}=0)$; 4$)$ "avoiding" age $(r=0,324, p=0)$. This indicates that the level and quality of social activity and related psychological qualities of young people increases if such respondents show older age, female gender, the presence of children and the growth of their number, living in the capital, the absence of a marriage partner. At the same time, the factor of "having children" is important for "leaders" (with the increase in their children, the manifestations of leadership qualities of the person increase). Factors of "sex" and "place of residence" - for "communicators" (women are more communicative, especially if they live in the capital: the socially enriched environment of a big city gives them selfconfidence, increases their self-esteem). For "aggressive"thre is a characteristic feature such as "no family person". It is under these conditions that they are more active in social activities. Finally, the socially active young person of older age turned out to be more moderate and "avoidant", i.e. in the organization of their own activity the "age" part of the youth is mainly guided not by motivation to succeed, but rather by motives of "avoiding failure", which is a safer behavior strategy.

5. The results of the survey of socially active youth have showed that the respondents adequately identified many conditions, methods of development of 
psychological qualities of socially active youth, among which the leading place is occupied by socio-psychological training. Therefore, the idea of developing and testing a training program for the development of psychological qualities of socially active youth has become the main goal of the formative stage of the current study. In accordance with this goal, the following tasks have been set:

1. To develop the content and structure of the training program for the development of psychological qualities of socially active youth, based on the results of empirical research.

2. To test the program of development of psychological qualities of socially active youth.

3. Investigate the effectiveness of the training based on the comparison of data before and after the implementation of the program of socio-psychological training.

The implementation of the tasks has been done in three stages of the formative experiment. Initially, based on an empirical study of the psychological qualities of socially active youth, a list of those psychological qualities that need further development to increase the productivity of social activity of young people has been identified, the structure of training has been created, and also those theoretical questions which need to be opened by the trainer at realization of an information part of the program have been defined.

The content of the program includes seven training sessions: "Social activity and its role in the life of the individual and society"; "Features of social activity of youth and its main directions"; "Psychological qualities of socially active youth: content and structure"; "Leadership potential as an important quality of socially active youth"; "Valuemotivational basis of social activity of youth"; "Emotional-regulatory qualities of social activity of youth"; "Communicative potential of socially active youth". The first three sections of the training are informative and are implemented in the form of lectures with elements of discussion and group work. The purpose of the next four sections is the formation and development of psychological qualities of participants. Therefore, they consist of practical exercises. After each lesson, training participants complete creative homework tasks. The introductory and final classes are aimed at the logical beginning (acquaintance) and completion of the whole cycle of classes and discussion by the participants of the received information and acquired skills.

The molding effect was carried out once a week for two months. The total volume of the training program is 60 academic hours: 7 training sessions (6 academic hours each), 2 acad. year introduction to training; 2 acad. year completion of training and 14 hours of individualbwork (to perform psychodiagnostic and creative tasks). Training programs carried out based on the charitable organization "Foundation for psychological support in crises "Ancora". The training was systematic, holistic in accordance with the content and purpose of the training aimed at developing the psychological qualities of socially active youth.

To determine the effectiveness of the training, a group of 52 study participants was selected ( 26 people - the experimental 
group and 26 people - the control group). At the beginning and after the training, we did the diagnosis of psychological qualities necessary for the social activity of a young person in accordance with the components identified in our work. The obtained data were processed by comparing two dependent samples by the method of Student's t-test. This method makes it possible to determine the presence and significance of changes in the parameters of the object over time on the same sample (see Table 2).

Table 2. The results of the effectiveness of training in the experimental group (according to the first and second diagnostic sections)

\begin{tabular}{|l|c|c|c|c|}
\hline \multirow{2}{*}{ Psychological qualities } & $\begin{array}{l}\text { I cut (before } \\
\text { training) }\end{array}$ & $\begin{array}{l}\text { II cut (after } \\
\text { training) }\end{array}$ & \multicolumn{1}{|c|}{$\begin{array}{l}\text { Student's t- } \\
\text { test }\end{array}$} & $\begin{array}{l}\text { Significance of } \\
\text { differences }\end{array}$ \\
\cline { 2 - 3 } & 18,0 & 21,0 & $-1,364$ & 0,174 \\
\hline Communication skills & $21,0^{* * *}$ & $21,6^{* * *}$ & $-3,277$ & 0,001 \\
\hline Organizational skills & $16,32^{* * *}$ & $21,66^{* * *}$ & $-4,093$ & 0,0001 \\
\hline Leadership & $13,35^{* *}$ & $15,0^{* *}$ & $-2,733$ & 0,007 \\
\hline Altruism - selfishness & $24,36^{* *}$ & $26,16^{* *}$ & $-2,873$ & 0,005 \\
\hline Achieving success & 20,64 & 22,2 & $-1,345$ & 0,181 \\
\hline The desire for power & 21,72 & 22,8 & $-1,001$ & 0,318 \\
\hline Tendency to affiliation & $19,9^{* * *}$ & $23,3^{* * *}$ & 5,726 & 0,001 \\
\hline Acertive actions - & $21,3^{* * *}$ & $23,0^{* * *}$ & $-3,452$ & 0,001 \\
\hline Entering social contact & 23,3 & 23,7 & $-0,672$ & 0,503 \\
\hline Search for social support & 20,0 & 20,6 & $-1,235$ & 0,219 \\
\hline Precautions & 18,5 & 17,2 & 0,844 & 0,400 \\
\hline Impulsive actions & $17,3^{* * *}$ & $13,2^{* * *}$ & 3,337 & 0,001 \\
\hline Avoidance & 19,2 & 18,7 & 0,343 & 0,732 \\
\hline Manipulative actions & $16,5^{* * *}$ & $13,6^{* * *}$ & 3,544 & 0,001 \\
\hline Antisocial actions & $18,6^{* * *}$ & $13,0^{* * *}$ & 5,350 & 0,0001 \\
\hline Aggressive actions & 21,67 & 15,75 & 1,750 & 0,082 \\
\hline Frustration & $17,93^{* * *}$ & $19,05^{* * *}$ & $-5,330$ & 0,0001 \\
\hline Assertiveness & $16,8^{* *}$ & $18,9^{* *}$ & $-2,631$ & 0,009 \\
\hline Communicative control & $\mathrm{n}$ & \\
\hline
\end{tabular}

*** $\mathrm{p}<0,00 ; * * \mathrm{p}<0,01 ; * \mathrm{p}<0,05$

According to the results of statistical analysis of experimental data before and after impact, the difference was significant on the following scales: organizational skills $(\mathrm{t}$ $=-3,277 ; \mathrm{r}=0,001)$, leadership $(\mathrm{t}=-4,093 ; \mathrm{r}=0)$, altruism $(\mathrm{t}=-2,733 ; \mathrm{r}=0,007)$, success $(\mathrm{t}=-2,873 ; \mathrm{r}=0,005)$, assertive actions $(\mathrm{t}=-5,726 ; \mathrm{r}=0)$, assertiveness $(\mathrm{t}=$ $5,330 ; \mathrm{r}=0)$, entering social contact $(\mathrm{t}=-3,452 ; \mathrm{r}=0,001)$, avoidance $(\mathrm{t}=3,337 ; \mathrm{r}=$ $0,001)$, antisocial actions $(\mathrm{t}=3,544 ; \mathrm{r}=0,001)$, aggressive actions $(\mathrm{t}=5,350 ; \mathrm{r}=0)$, communicative control $(\mathrm{t}=-2,631 ; \mathrm{r}=0,009)$.

In the control group, where with an interval of 2 months, the relevant psychodiagnostic measurements were also performed, no significant differences in the indicators of social activity of the participants were found.

Based on the data obtained, it can be argued that the training "Development of psychological qualities of socially active youth" is effective, because after its implementation, the participants have increased the expression of such qualities as: organizational skills, leadership, altruism, success, assertiveness, communicative control of the entering the social contact desire, and decreased levels 
of behavior strategies such as "avoidance", "antisocial actions" and "aggressive actions". That is, changes took place among all personal spheres in which psychological qualities of socially active youth were allocated. Thus, it is possible to make a conclusion that as a result of formative experiment there were positive shifts in development of psychological qualities of socially active youth. The data obtained in the process of conducting a formative experiment indicate the high efficiency of training and the expediency of its use for the psychological preparation of young people for social activity.

\section{Discussion}

In the organization and implementation of the study of psychological qualities of socially active youth, a non-classical methodology has been used, built using systematic, comparative-typological and integrated approaches. The combination of psychological, sociological and statistical means of diagnosis and psychologicalpedagogical and socio-psychological tools of development have allowed the authors to determine psychological characteristics of such persons more adequate, to define objective and subjective factors of productivity of their activity, personal resources and psychological and pedagogical opportunities for their further development.

The obtained results have allowed the authors to move away from the

\section{Conclusions}

1. Modern Ukrainian youth adequately understands the content of social activity as an activity that contributes to the improvement of life in various social spheres and social interpretation of a socially active personality in its canonical vision as a young person who demonstrates a set of highly developed characteristics inherent in the theoretical model of psychological qualities of such a person. The study has found that only a third of its socially active participants (32.5\%) showed the expected compliance. Instead, most socially active respondents have psychological characteristics that not only promote but also limit the productivity of their prosocial activity. The study has identified 4 types of such socially active people, the leading psychological qualities of which are: active communication (type 1), expressed aggression (type 2) - avoidance of contact (type 3) and impulsiveness (type 4). The presented typology indicates the need to develop and implement programs of psychological support for the development of psychological qualities of socially active youth, taking into account the specifics of their psychological profile, form and types of activity. The author's version of the program of diagnosis and basic psychological training of such persons is covered in this article. Obviously, depending on the psychological characteristics of each type, its representatives need not only general knowledge, skills and abilities necessary for social activity, but also special psychological support for further personal development. The development of appropriate programs for the development of psychological qualities of such socially active youth is a prospect of our study.

development in general. Various forms (volunteering, work in public associations, participation in social projects, etc.), directions (scientificeducational, social-psychological, cultural-artistic, etc.) of social activity in 
which modern youth is involved are allocated. There are also reasons that hinder the development of social activity of youth in Ukraine in modern socioeconomic conditions: lack of support from the state, inertia of youth, lack of funding, having the other cases and responsibilities, etc. At the same time, a significant number of respondents indicated that young people do not have the necessary psychological qualities to do the social activity.

2. According to the results of variance analysis, a statistically significant difference has been recorded between the two groups (socially active and socially inactive youth). Socially active youth prevails in terms of the development level of such psychological qualities as leadership ability, organizational skills, desire for power, assertiveness, manipulative actions, antisocial actions, while socially inactive youth has shown higher indicators of psychological signs of success.

3. With the help of factor and cluster analysis, the types of socially active youth have been identified according to the level of development of psychological qualities necessary for social activity ("leaders", "communicators", "aggressive", "avoidant", "impulsive"). It has been found that one third of respondents belong to the type of "leaders", and young people - representatives of the other four types, are not "leaders", but also manifest themselves in various areas of social activity (scientific, patriotic, sports, charity, etc.), making their special style of social activity. Therefore, in the process of interaction with groups of socially active youth should take into account the psychological characteristics of each of the types identified in the work, taking into account their positive characteristics and existing limitations.

4. As a result of correlation analysis, it has been proved that the involvement of a person in different areas of activity in different ways increase the level of development of psychological qualities necessary for social activity in representatives of different types. For "communicators" it is a sports, sociopsychological, military-patriotic sphere of activity, for "aggressive" it is a business sphere, and for "avoiding" socially active persons - a cultural and artistic sphere. The links between the types of socially active youth and the type of organization (public or private) in which the respondents work are also revealed: for "leaders" and "avoiders" the work in the state organization contributes to the increase of their psychological qualities development level. In addition, it was found that among the professional characteristics for the group of "leaders" important predictors are career growth in the organization and higher education; for the group of "avoiding" increase of the work experience leads to lower levels of psychological qualities. Among the sociodemographic characteristics having children is most positively influential for the group of "leaders", for the group of "communicators" - female gender and residence in the capital, for "aggressive" no family, for representatives of "avoiding" group such negative impact has the age increase of the respondents.

5. For the development and formation of significant personal qualities that help increase the productivity of social activity of Ukrainian youth, the training "Development of psychological qualities of socially active youth" has been created and tested. Based on statistically significant indicators, it has 
been proved that the respondents significantly increased the levels of altruism, organizational and leadership skills, communication control, motivation to succeed, assertiveness and decreased the level of manifestations of such traits as aggression, asociality, avoidance behavioral strategy.

Psychological conditions of development of psychological qualities of socially active youth, provided by the developed program, include mastering by participants of training: a) knowledge of psychological qualities of socially active youth; b) methods of diagnosis and analysis of their own psychological qualities necessary for the manifestation of social activity; c) skills and abilities necessary for social activities.

Further research is focused on expanding the possible ways of psychological support for the development of social activity of young people.

Acknowledgments. The study did not receive a grant from any financial agency in state, commercials or the non profit sector.

Conflict of interest. We state that there is no conflict of scientific interests.

\section{References}

Abulkhanova-Slavskaya K.A. (1985).

Tipologiya aktivnosti lichnosti.

[Typology of personality activity.] Psychological Journal. -

Psychological Journal. Volume 6 №5 1985. pp. 4-21. [in Russian]

Bazilenko AK (2017). Psykholohichni chynnyky formuvannya sotsial'noyi aktyvnosti student's'koyi molodi (na prykladi student's'koho samovryaduvannya). [Psychological factors of formation of social activity of student's youth (on an example of student's self-government).] The Dissertation on competition of a scientific degree of the candidate of psychological sciences on a specialty 19.00.07 - pedagogical and age psychology. - Open International University of Human Development "Ukraine". - Kyiv, 2017. [in Ukrainian]

Grabovska S, Czolij, S. (2010). Sotsial'na aktyvnist' u protsesi sotsializatsiyi osobystosti. [Social activity in the process of personality socialization.] Problems of general and pedagogical psychology - Problems of general and pedagogical psychology: coll. Science. etc. Institute of Psychology. GS Kostyuk, Academy of Pedagogical Sciences of Ukraine. Vol. XII, part 1, 171-181. [in Ukrainian]

Cherneta, S. (2015). Sotsial'na aktyvnist' osobystosti yak umova rozvytku suchasnoho ukrayins'koho suspil'stva. [Social activity of the individual as a condition of developmentmodern Ukrainian society.] Scientific Bulletin of the Lesia Ukrainka East European National University. № 1, 177-180. [in Ukrainian]

Karamushka, M. I. (2016) Socially active youth qualities development training program. Fundamental and applied researches in practice of leading scientific schools -Fundamental and applied researches in practice of leading scientific schools. 2016. No. 3 (15). P. 8-15.

Karamushka, M.I. (2020) Psykholohichni osoblyvosti rozvytku sotsial'noyi aktyvnosti molodi. [Psychological features of development of social activity of youth.] Dissertation ... Candidate of Psychological 
Sciences: 19.00.07 - K., Institute of Psychology Kostyuk G. S. NAPS of Ukraine-Kyiv, 2020. [in Ukrainian] Kulinchenko, OS (2015). Formuvannya sotsial'noyi aktyvnosti studentiv $\mathrm{v}$ umovakh diyal'nosti orhaniv samovryaduvannya vyshchoho navchal'noho zakladu. [Formation of social activity of students in the conditions of activity of bodies of self-government of higher educational institution.] Author's abstract dis. ... cand. ped. Science: 13.00.05. - Kyiv, 2015. - 23 p. [in Ukrainian]

Soroka, O. (2018). Diahnostyka sotsial'noyi aktyvnosti maybutnikh sotsial'nykh pratsivnykiv. [Diagnosis of social activity of future social workers.] Social Work and Education. -Social Work and Education, Vol. 5, no. 2., pp. 66-76.

Stupak, O.Yu. (2019). Systema formuvannya sotsial'no aktyvnoyi molodi $\quad \mathrm{V}$ instytutakh hromadyans'koho suspil'stva: informatsiynyy etap. [The system of formation of socially active youth in civil society institutions: information stage.] Bulletin of KNLU - Bulletin of KNLU 2019. Series pedagogy and psychology Issue 13 p.148-154. [in Ukrainian]

Tatenko, V. (2017). Metodolohiya sub"yektno-vchynkovoho pidkhodu: sotsial'no - psykholohichnyy vymir: monohrafiya. [Methodology of subject-action approach: sociopsychological dimension: monograph.] - К.: Мілениум, 2017. - 184 c. [in Ukrainian]

Vlasova, O., Kalenichenko K., (2020). The effectiveness of the psychological support program of the personal-professional growth of the state employment service of Ukraine personnel reserve. Socialization and Human Development: International Scientific - Socialization and Human Development: International Scientific Vol. 2 № 1 2020. ttps: //doi.org/10.37096/SHDISJ-20-1.10011.

Vlasova, E.I. (1989). Lichnostnyye mekhanizmy sotsial'noy aktivnosti podrostkov. [Personal mechanisms of social activity of adolescents.] Abstract of the dissertation... Candidate of Psychological Sciences. On the rights of the manuscript - K., 1989 -17p. [in Russian]

Yanovska, S., Turenko, R. (2018). Perezhyvannya vlasnoho vyboru ta osobystisni yakosti lideriv student's'koho samovryaduvannya. [Experiences of one's own choice and personal qualities of leaders of student self-government.] Bulletin of VN Karazin Kharkiv National University - Bulletin of VN Karazin Kharkiv National University. Psychology Series, 2018 (64), 71-74. https://periodicals.karazin.ua/psycho $\underline{\operatorname{logy} / \text { article/view/11259 } \quad \text { [in }}$ Ukrainian] 